\title{
EPWORTH SLEEPINESS SCALE OUTCOME IN 616 BRAZILIAN MEDICAL STUDENTS
}

\author{
FLÁVIO ALÓE*, ANDRÉ PEDROSO**, STELLA MÁRCIA TAVARES ***
}

\begin{abstract}
The Epwotth Sleepiness Scale (ESS) measures daytime sleepiness in adults. This paper reports the following data in 616 medical students: 1-ESS scores, 2-its conrelation with the declared night sleep time, 3-comparison with ESS values obtained from Australia, 4-comparison of ESS values in a sub-population of 111 students tested early and late 1995 . There were 387 males, 185 fernales and 4 not specified. Age $=20.16 \pm 2.23$ (SD). ESS score $=$ $10.00 \pm 3.69$ (SD), declared sleep time $=7.04 \pm 1.03$ (SD). ESS scores did not statistically correlate with sleep time. Average ESS score was statistically higher than in the Australian sample. Retesting of the medical students showed an increase in ESS values from March to November 1995. Sleep time difference was non-significant. Higher ESS scores in this sample seem to be related to shorter sleep time, but fatigue effects can not be ruled out.
\end{abstract}

KEY WORDS: sleepiness, nighttime sleep, medical students, Epworth, questionnaire.

\section{Desempenho na Escala de Sonolência de Epworth de 616 estudantes de medicina brasileiros}

RESUMO - A Escala de Sonolência de Epworth (ESE) mede sonolência diurna em adultos. Este estudo relata os seguintes dados de 616 alunos de medicina da Faculdade de Medicina da Universidade de São Paulo: 1 - média de ESE, 2- sua correlação com o nuímero de horas de sono, 3- comparação com a média obtida na Austrália, 4- comparação đos valores de 111 alunos testados no início e no final de 1995. Valor médio da $E S E=10,00 \pm 3,69$ (DP). Horas de sono $=7,04 \pm 1,03$ (DP). Os valores de ESE nāo se correlacionaram estatisticamente com o tempo de sono. A média da ESE foi estatisticamente maior que na amostra australiana. O reteste mostrou aumento nos valores da ESE de março a novembro de 1995, sem diferença estatística no número de horas de sono. Os valores mais altos da ESE nesta populaçāo parecem estar relacionados com sono mais curto mas os efeitos da fadiga não podem ser afastados.

PALAVRAS-CHAVE: sonolência, sono notuıno, estudantes de medicina, Epworth, questionário.

Excessive daytime sleepiness (EDS) can be defined as the difficulty to keep a desired alertness level or excessive quantity of sleep during the day ${ }^{2.17,31}$. It can be an incapacitating symptom, causing family and social problems, accidents, unemployment or school troubles ${ }^{31}$. Initially recognized as an important symptom by the end of the 1960's, EDS was related to unruled lifestyle, laziness or malingering. EDS is frequently neglected by doctors and patients ${ }^{4}$. Sleepy patients incorporate it as a habit or deny being sleepy because of the erroneous social links with laziness. EDS can be a symptom of a potentially lethal disease in middle age adults, namely, obstructive sleep apnea syndrome ${ }^{2}$ Several population studies demonstrate that around 0.5 to $5 \%$ of the general population show daytime sleepiness $^{3.5 .211 .31 .34}$. Approximately $25 \%$ of the developed countries work force engaged in shift work complains of sleepiness symptoms ${ }^{1.22}$. More than half of the patients with EDS report either automobile

* Sleep-Wake Disorders Center (CIES) of the Faculty of Medicine of the University of São Paulo General Hospital (Hospital das Clínicas), São Paulo, Brazil: *MD,Attending Neurologist; **Medical student; ***:k MD, Attending Clinical Neurophysiologist and Coordinator for the Sleep Laboratory of the Hospital Israelita Albert Einstein, São Paulo, Brazil. Aceite: 3-dezembro-1996. 
or occupational accidents ${ }^{x}$. Life expectancy data directly link sleep and mortality where men and women sleeping more than 10 hours a day were about 1.8 times more likely to die prematurcly than those sleeping 7-8 hours daily". Sleep is a homeostatic function of the organism. Sleepiness is a physiological state like hunger and thirst, which are necessary states basic to the survival ${ }^{10.31}$. Sleep deprivation increases sleepiness and, as hunger and thirst are reversible by eating and drinking, sleeping relieves sleepiness.

\section{Determinants of sleepiness}

1. Sleep Amount. The degree of daytime sleepiness is directly related to the amount of nocturnal sleep obtained. Insufficient sleep quantity produces objectively and subjectively measured daytime sleepiness in several populations ${ }^{12}$. Even small reductions of one hour of sleep per night causing accumulated sleep deprivation produccs daytime sleepiness ${ }^{12}$. Altcrnatively, sleep extension reverses sleepiness".

2. Sleep Quality. Daytime sleepiness is closely related to the continuity of sleep. Sleep in patients with certain slcep disorders is punctuated by frequent, bricf arousals, 3 to $15 \mathrm{sec}$ long ${ }^{\prime \prime}$. Apnens, pain and leg myoclonus may produce repetitive arousals which usually go unrecalled by the patient $^{10.36}$. The critical point is that arousal does not result in shortened sleep but in discontinuous sleep causing daytime sleepiness ${ }^{6.7 .111 .36}$. Correlational data show a link between sleep fragmentation and daytime sleepiness ${ }^{6.7 .110 .36}$. Experimental sleep fragmentation in healthy adults has been produced by awakening by sound stimulus. These studies have shown performance reduction and daytime sleepiness on the following day ${ }^{\text {i.? }}$.

3. Circadian Rhythms. A biphasic pattern of objective daytime sleepiness is well represented in young adults and healthy elderly subjects ${ }^{31}$. This biphasic pattern was experimentally determined in young adults and elderly subjects tested for sleep latencies each two hours during a full 24-hour period $^{25.31}$. Two somnolence peaks were recorded, onc between 0100 and $0600 \mathrm{~h}$, and the second between 1400 and $1800 \mathrm{~h}^{13.29}$. This circadian sleepiness rhythm is part of a circadian system ${ }^{25}$. The acutc sleepiness that shift workers and transmeridional flights travelers experience resulis from the placcment of sleep and wakefulness at times that are out of phase with the pre-existing circadian rhythm 25,20 .

4. Drugs and Medication. Central nervous system depressant agents produce sleepincss. Benzodiazepines, barbiturates, alcohol and $\mathrm{H}-1$ anti-histamines all increase objective and subjective sleepiness ${ }^{24.30 .32 .33}$. Stimulating medication such as amphetamines, methylphenidate, pemoline and caffeine increases alertness, and withdrawal of these substances may unmask or exaccrbatc sleepines $\mathrm{s}^{2 n}$.

EDS can be measured objcctively and subjectively. The Multiple Sleep Latency Test (MSLT) is the gold standard for objective measurement of physiologic sleepiness but it is a difficult and expensive test to perform ${ }^{4.13 .2 x}$ Alternatively, several subjective sleepiness scales were produced. namely, the Stanford Sleepiness Scale, visual analogic scales and the Epworth Sleepiness Scale $(\mathrm{EES})^{15.16 .18 .119}$.

The authors report the ESS score values of 616 University of São Paulo Medical Students. The study objectives were to determine: 1 . ESS scores in University of Săo Paulo Medical School student population, 2. its correlation with the declared night slecp time, 3. comparison with values obtained from medical Australian students in an analogous study, 4. comparison of ESS values in a subpopulation of 111 first-year medical students who were tested in early 1995 and subsequently in late 1995.

\section{MATERIAL AND METHODS}

The ESS is a self-administered eight-item questionnaire that has been proposed as a simple method for measuring daytime slecpiness in adults ${ }^{1 \times, 14}$. The ESS is easy to apply and it consists of a self-administered 8 item questionnaire. The subject estimates his likelihood (range 0 to 3 ) to fall asleep in 8 different coutine situations. ESS score ranges from 0-24 in an increasing order of sleepiness and it has been validated by the MSLT ${ }^{1 \times .11}$. A Portuguese translation of the ESS was produced and demographic questions were added such as 
gender, ethnic group and estimated sleep time, use of medication or alcohol (Appendix). Minimal inclusion ctiteria for the study was the rating of the eight sleep inducing situations and estimated number of hours of slecp. A brief explanation was provided, stressing to the students that the ESS should reflect the last few months.

The ESS was applied to 479 students (first through fourth year) in November and December 199427. Additional 165 first-year students were tested in March 1995, and 138 of them were retested in November 1995. A total of 616 students tested in late 1994 and 1995 constitutes this study's entire sample. Out of the 165 first-year students tested in early 1995, only 111 subjects were identified and included for retesting analysis. The entire sample's average ESS score was compared to an analogous sample of 104 Australian medical students".

Statistical analysis. ESS scores of 616 students tested at the end of the school year were correlated to their sleep time using the simple linear regression. The averaged ESS scole was compared to the sample from Australia using Student's T-test. Different student subpopulations were also analyzed using the One-Way ANOVA. The 111 first-year students identified to compound the retest sample had their ESS values on both occasions compared using the Student's Paired T-tesi.

\section{RESULTS}

There were 387 males, 185 females and 4 not specified. Average age $=20.16 \pm 2.23$ (SD). White Caucasian $=442$; Asian $=113$; Afro-Brazilian $=4$; other $=13 ;$ not specified $=44$. No distinction between Caucasian and Hispanic ethnic groups was made. Avcrage ESS score $=10.00 \pm 3.69$ (SD); range 0 to 21 points (Fig 1). Declared sleep time $=7.04 \pm 1.03(\mathrm{SD})$, range $=4$ to $11 \mathrm{~h}$. No correlation between average ESS score and average declared sleep time, was recorded (Pearson's $\mathrm{r}=0.02 ;-0.06$ $<R<0.10 ; p=0.05$ ) (Fig 2). The Asian individuals demonstrated a significantly higher ESS average score compared with the Caucasian sub-population (10.53 \pm 3.51 (SD) vs $9.62 \pm 3.48$ (SD); $\iota=2.91$, $\left.\mathrm{t}_{\text {criticil }}=2.58, \alpha<0.01\right)$, for a non-significantly different declared sleep time $(6.88 \pm 1.06$ (SD) vs 7.09 $\left.\pm 1.02(\mathrm{SD}) ; \mathrm{t}=1.93, \mathrm{t}_{\text {criticil }}=1.96, \alpha<0.05\right)$. These two ethnic groups were compared because of the very low representativeness of the others. No statistically significant difference was determined for average ESS scores regarding distinct medical schooling years $(F=0.891 ; d f=4 ; p=0.53$ ). No statistically significant difference was determined for three different declared sleep time length (stl) subgoups (stl $<6.5 \mathrm{~h}, 6.5 \mathrm{~h}<\mathrm{stl}<7.5 \mathrm{~h}$ and $\mathrm{stl}>7.5),(\mathrm{F}=1.194 ; \mathrm{df}=2 ; \mathrm{p}=0.3034)$.

A statistical difference for average ESS scores of our entire sample was recorded when compared to Australian students (ESS $=7.6 \pm 3.9$ (SD) $; \mathrm{t}=5.85, \mathrm{t}_{\text {criticil }}=3.291, \alpha<0.001$ ). Sleep time

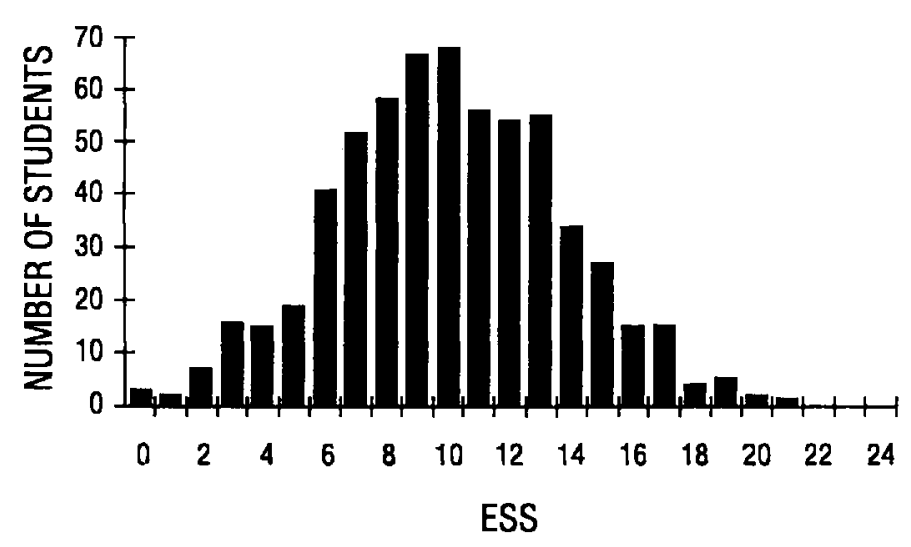

Fig I. ESS histogram. The scores are distributed in an approximately normal curve, with $m e a n=10.00 \pm 3.69(S D)$. 


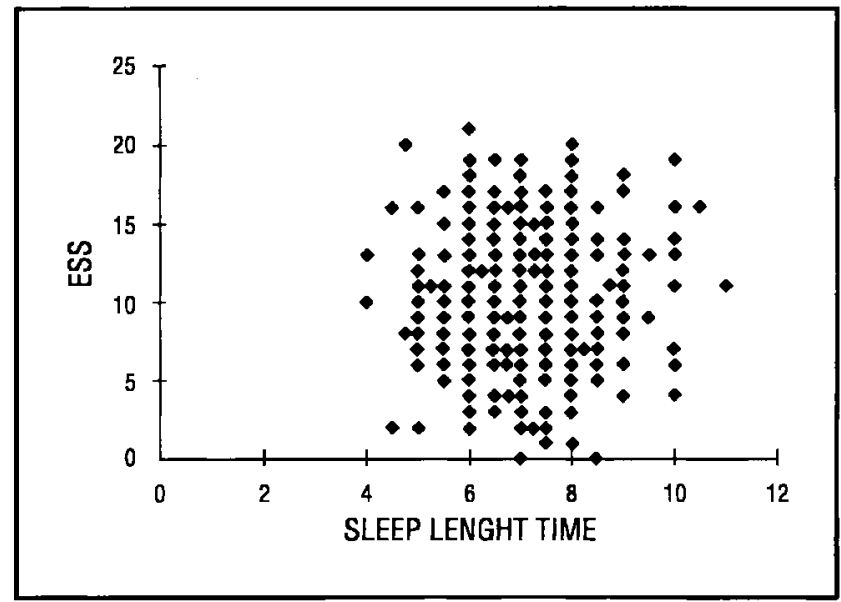

Fig 2. ESS $x$ Sleep Time Length. No correlation between these variables was found.

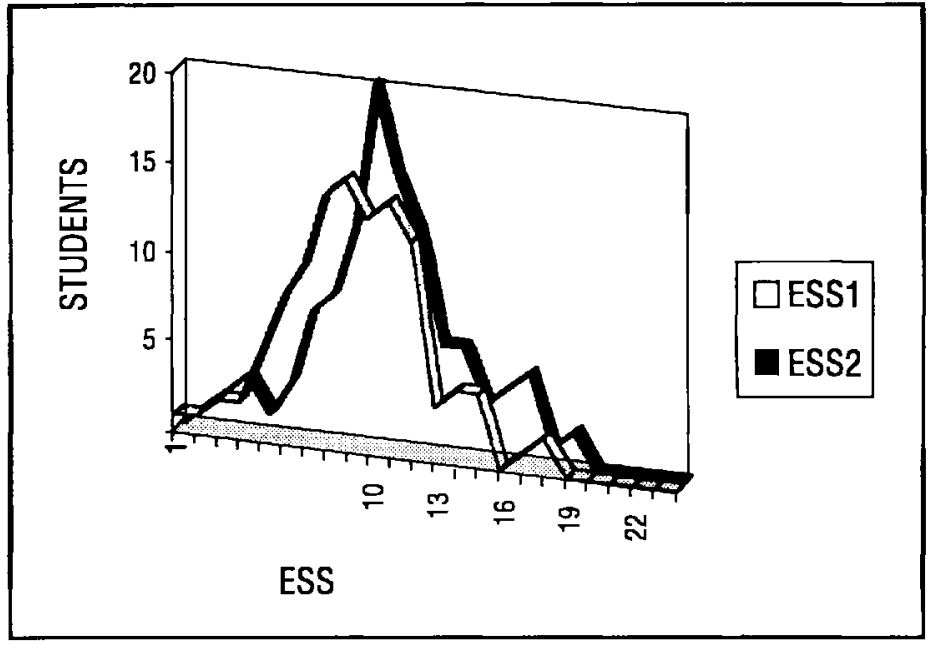

Fig 3. ESS early and late in 1995. The retesfed population had higher ESS scores late in the year (ESS 2).

was statistically shorter in our sample compared to Johns' weekday sleep length (stl=7.7 \pm 0.07 (SD); $\mathrm{t}=15.69 \mathrm{t}_{\text {critical }}=3.291, \alpha<0.001$ ).

Retesting outcome of 111 students made evident an increase of averaged ESS scores (early 1995 $=9.40 \pm 3.19(\mathrm{SD}) ;$ late $\left.1995=10.68 \pm 3.44(\mathrm{SD}) ; \mathrm{t}=9.12, \mathrm{t}_{\text {criticil }}=3.291, \alpha<0.001\right)$ (Fig 3). Declared sleep length difference was non-significant $\left(7.12 \pm 0.89\right.$ (SD); $6.97 \pm 1.02(\mathrm{SD}) ; \mathrm{t}=0.075 \mathrm{t}_{\text {criat:al }}=1.96, \alpha<0.05$ ).

\section{DISCUSSION}

The ESS is recognized for measuring excessive daytime sleepiness ${ }^{1 \% .19}$. ESS scores significantly distinguished groups of patients who are known from other investigations to have differences in their levels of sleepiness measured by the MSLT ${ }^{18}$. Additional studies confirm the ESS reliability and internal consistency ${ }^{19}$. There was no statistical correlation between ESS and sleep time length in this study sample. Therefore, sleep length time cannot be considered a predictive factor for ESS 


\section{HOSPITAL DAS CLÍNICAS DA FACULDADE DE MEDICINA DA UNIVERSIDADE DE SÃO PAULO \\ CENTRO INTERDEPARTAMENTAL PARA ESTUDOS DO SONO \\ CIES}

\section{ESCALA DE SONOLENCIA EPWORTH}

Iniciais + data de rascimento

Idade

Peso

Altura

Data Grupo étnico Sexo [ ] F [ ] M Horas de sono/noite

Ano de graduação Plantonista [ ] sim [ ] não Dotme às Acorda às
Medicaçāo
Älcool antes de dormir [ ] sim [ ] não

Qual é a probabilidade de você "cochilar" ou adormecer nas situações que serão apresentadas a seguir, em contraste com estar sentindo-se simplesmente cansado? Isto diz respeito ao seu modo de vida comum, nos tempos atuais. Ainda que você não tenha feito, ou passado por nenhuma destas situações, tente calcular como poderiam tê-lo afetado.

Utilize a escala apresentada a seguir para escolher o número mais apropriado para cada situação

0 = nenhuma chance de cochilar $\quad \mathrm{L}$ = pequena chance de cochilar

2 = moderada chance de cochilar 3 = alta chance de cochilar

SITUAÇÃO

CHANCE DE COCHILAR

Sentado e lendo

Vendo TV

Sentado ern um lugar público

( ex. sala de espera, igreja )

Como passageiro de trem, carro ou ônibus

andando uma hora sem parar

Deitando-se para descansar à tarde, quando as circunstâncias permitem

Sentado e conversando com alguém

Sentado calmamente após almoço sem álcool

Se você tiver carto, enquanto pára por alguns minutos quando pega trânsito intenso

TOTAL 
scores in this sample. However, comparison of our 616 students to the Australian students who had both statistically significant lower ESS average scores and longer sleep time suggests a rolc for slcep deprivation. The statistically significant increase in ESS scores for the retested sample along with a non-significant decrease in sleep time length points out to less sleep time not being a factor for increased ESS values. This increase in ESS scores may indicate the presence of fatigue or an external factor because sleep length did not differ in a statistically significant way from March to November 95. The data from all the 616 students were collected at the end of school year in the Southern hemisphere (November and December 94 and 95), therefore a fatigue factor or other factors emerging in the school-year may play a role. Young medical students frequently carry out their lives in a frantic way, often leading to a departure from their original lifestyles. They have to acquire an enormous amount of information in short periods of time while undergoing the hardships of the medical practice. Curtailing sleep time is part of the student's coping strategy with consequent sleepiness. Increasingly, contemporary culture has seen an expasion of the daily work period with a reduction in the time available for sleep ${ }^{35}$.

Essentially, EDS is caused by fragmented sleep, circadian rhythm changes, drugs, aging and sleep disorders. Except for aging and sleep disorders, these factors belong to certain extent to many medical students' life. Wolf and Kissiling ${ }^{37}$ described a reduction of quantity and quality of sleep, physical activity and leisure time and increased stress in medical students during their first schooling year.

This can cause a fatigue effect that may be subjectively interpreted as sleepiness. Additionally, our tested population was composed of young adults, who are sleepier than the general population ${ }^{14.23}$. Interpretation of the scale in English and Portuguese may be different enough to cause a comparison bias. Finally, the scale itself may not be appropriate to estimate sleepiness in normal individuals, since it may measure factors other than sleepiness.

We conclude that higher ESS scores in this sample seem to be related to shorter sleep time but fatigue effects can not be rulcd out.

\section{REFERENCES}

1. Akcrsted T. Frober JE. Shift work and health: interdisciplinary aspects. In Rentos PG R, Sliepard RD (cds). Shift work and lieilth: i symposium. Washington DC: NIOSH, 1976:179-197.

2. Aldrich MS. Cardinal manifestations of sleep disorders. In: Kryger MH. Roth T. Dement WC (eds). Principles and practice of sleep medicine. New York: WB Siunders, 1989:313-319.

3. Billiard M. Alperovitch A, Perot C, Jamnes A. Excessive daylime somnolence in young nen: previlence and contributing factors. Sleep 1987;10:297-305.

4. Bixler ED, Kales JB, Scharf MB, et al. Incidence of sleep disorders in medical practice: a physician survey. Sleep Res 1976:5:160.

5. Bixler ED. Kales A. Soldatos CR. Kiles JB. Prevalence of sleep disorders in the Los Angeles netropolitiun alrei. Am .I Psychiatry 1979;136:1257-1262.

6. Bonnet MH. The effect of sleep distuption on pertiormance, slecp and mood. Sleep 1985:8: II- 19 .

7. Bonnet MH. Performance and sleepiness as a function of the frequency and plicement of slecp disruption. Psychophysiology 1986;23:263-27।.

8. Brougliton R. Ghanem Q, Hishikawa Yet al. Life effects of niucolepsy in 180 paticnts trom North America. Asia, and Europe compared to matclied controls. Can J Neurol Sci 1981;8:299-304.

9. Carskidon MA Guidelines for the Multiple Sleep Latency Test (MSLT): a standiud measure of sleepiness. Slecp 1986;9:519-524.

10. Carskadon MA. Brown ED. Dement, WC. Sleep fragmentation in the elderly: relationship to daytime slecp tendency. Neurobiol Aging 1981:23:321-327.

11. Carskadon MA, Dement WC. Sleepincss during extension of nocturnal sleep. Sleep Res 1979:8:147.

12. Curxkation MA. Dement WC. Cumulative effects of sleep restriction on daytime sleepiness. Psychophysiology 1981:18:107-I13.

13. Carskadon MA, Dement WC. The multiple sleep latence test: what does it mealsure ? Sleep 198.5: 5(Suppl): S67-S72.

14. Curskadon MA. Denent WC. Sleepiness in the nornal adolescent. In Guilleminault $C$ (ed). Sleep and its clisorders in children. New York: Raven Press. 1987:53-65.

15. Herbert M. Johns ME. Doté C. Factor analysis of analogue scales measuring subjective feclings before and after slecp. 13r I Med Psychol 1976;49:373-379.

16. Hoddes E. Zitcone V, Smythe H. Phillips R, Dement WC. Quantification of sleepiness: a new approach. Psychophysiology 1973:10:43]-436. 
17. ICSI)-Intemational Classification of Sleep Disorders. Diagnostic and coding manual. Diagnostic Classification Steering Committes. Thorpy MJ, Chiirmin. Rochester, Minnesota: American Sleep Disorders Association, 1990.

18. Johns MW. $\Lambda$ new method for meatsuring ditytime sleepiness: the Fpwoth Sleepiness Scile. Sleep 1991:14:540-545.

19. Johns MW. Reliability and factor analysis of the Epworth Slecpincss Scale. Slecp 1992;15: 376-381.

20. Karacan 1, Tlionby II, Anch M et al. Sleep disturbance in a primary urban Florida county. Soc Sci Med 1976;10:239-244.

21. Kripke DF, Simmons NR, Gartinkel L. Hammond EC. Shott and long sleep and sleeping pills: is increased mortality associated? Arch Gen Psychiatiy 1979:36:103-116.

22. Livic P. Sleep habits and sleep disturbances in in industrial workers in Israel: main findings and some chatracteristics of workers complaining of excessive daytime sleepiness. Sleep 1981;4:147-158.

23. Levine 13. Rochs' T, Zorick J; Roth T. Daytime sleepiness in young adults. Sleep 1988;1 1:39-46.

24. Maclein $\Lambda$, Caims J. Dose-response effects of ethanol on the sleep of young men. J Stud AJcohol I 982;43:433-444.

25. Nicholson AN, Pascoe PA, Spencer, MB, Stone MB, Roehrs T, Roth T. Sleep after transmeridian flights. Lilncet 1986;2: 1205-1208.

26. Parkes JD, lenton GW. Levo (-) amphetemine and dextro (+) amphetamine in the treatment of narcoplesy. J Neurol Neurosurg Psychiatry 1973:36:1076-1081.

27. Pedroso A. Clieroto-Fillio A. Resultados da Escala de Sonolência de Epworth (ESE) em 480 alunos de graduação da Faculdade de Medicina da Universidade de São Paulo. Revista Medicina (São Paulo) 1996;75(2) (in press).

28. Richirdson GS. Cirskildon MA, Flagg W, Van Den Hoed J, Dement WC. Mittler MM. Excessive daytime sleepiness in matn: multiple slesp littency measurements in nurcoleptic vs. control subjects. Electroenceph Clin Neurophysiol 1978;45: 621-627.

29. Richardson GS. Carskadon MA, Orav EJ, Dement WC. Circadian valtiation of sleep tendency in elderly and young adults subjects. Sleep 1982; 5(Suppl): S82-S94.

30. Rochrs T, Tietz E, Zorick F, Roth T. Daytime sleepiness and antihistamines. Sleep 1984;47:137-41

31. Roth T. Roehrs T. Carskiddon MA. Dement WC. Daytime sleepiness and alertness. In Kryger MH, Roth T, Dement WC (eds). [rinciples und plactice of sleep medicine. Ed 2. New York: WB Saunders, 1994:40-49.

32. Rath T, Zorick F, Sicklesteel J, Stepanski E. Effects of benzodiazepines on slecp and wakefullness. Br J Clin Pharmacol $1981 ; 1\}$ (Suppl): S31-S35.

33. Roth T, Zorick F, Wittig R, Rochrs T. Phatmacological and medical considerations in hypnotic use. Sleep 1982:5(Suppl):S46-S52.

34. Schmidh-Nowaril WW, Wiggins CL. Walsh JK, Bauer C. Prevalence of sleepiness in an adult population. Sleep Rex 1989;18:302.

35. Schor JB. The overworked American. New York: Basic Books, 1991.

36. Steparnski L, L imphere J, Roehrs T, et al. Experimental sieep fragmentation in normal subjects. Int J Neurosci I987;33:2042I4

37. Wolf TM, Kissling GE Changes in life-style characteristics, health, and mood of freshman medical students. J Med Educ 1984:59:806-814. 